\title{
Some Empirical Aspects of Multi-sided Platform Industries
}

\author{
DAVID S. EVANS*
}

NERA Economic Consulting

\begin{abstract}
Multi-sided platform markets have two or more different groups of customers that businesses have to get and keep on board to succeed. These industries range from dating clubs (men and women), to video game consoles (game developers and users), to payment cards (cardholders and merchants), to operating system software (application developers and users). They include some of the most important industries in the economy. A survey of businesses in these industries shows that multi-sided platform businesses devise entry strategies to get multiple sides of the market on board and devise pricing, product, and other competitive strategies to keep multiple customer groups on a common platform that internalizes externalities across members of these groups.
\end{abstract}

\section{Introduction}

Multi-sided platforms coordinate the demand of distinct groups of customers who need each other in some way. Dating clubs, for example, enable men and women to meet each other; yellow pages provide a way for buyers and sellers to find each other; and computer operating system vendors provide software that applications users, applications developers, and hardware providers can use together. When devising pricing and investment strategies, multi-sided platforms must account for interactions between the demands of multiple groups of customers. In theory, the optimal price to customers on one side of the platform is not based on a markup formula such as that given by the Lerner condition, and price does not track marginal cost. Competition among platforms takes place when seemingly distinct customer groups are connected through interdependent demand and a platform that, acting as an intermediary, internalizes the resulting indirect network externalities (Rochet and Tirole, 2003). Platforms are central to many key industries including computer games, information technology, many internet-based industries, media, mobile telephony and other telecommunications industries, and payment systems.

* David S. Evans. Senior Vice President. NERA Economic Consulting, 1 Main Street, Cambridge, MA, 02142. Email: David.Evans@NERA.com The author is extremely grateful to Howard Chang, Richard Bergin, Lauri Mancinelli, John Scalf, Nese Nasif, and Bernard Reddy for their many contributions to the research upon which article is based. This paper draws material from "The Antitrust Economics of Two-Sided Markets" available at http://aei.brookings.org/admin/pdffiles/phpMt.pdf. 
This article provides an empirical survey of entry, pricing and other strategies in platform industries. It provides background for the emerging theoretical (Rochet and Tirole, 2003; Julien, 2001; Armstrong, 2002; and Parker and Van Alstyne, 2002); empirical (Rysman, 2002), and policy (Evans, 2003) literature on multi-sided platform markets. Although it does not provide empirical tests of either the key assumptions of this literature or its implications, it confirms that multi-sided platforms are an important, and until recently unrecognized, part of the industrial organization landscape, and that this new area of economic research has potentially rich empirical implications and relevance. This article is based, and reports early results, of a series of detailed case studies of multi-sided platform industries I have been conducting.

Section 2 summarizes the conditions under which a multi-sided platform may emerge and the main theoretical findings of the literature to date. It also provides a brief overview of the three major kinds of platforms. Section 3 reviews some common business practices followed in multisided platform industries studied thus far. I then turn to two more detailed case studies. Section 4 reviews the entry of Diners Club in the payment card industry and summarizes the pricing strategies that continue to this day. Section 5 examines the entry of the Palm operating system for personal digital assistants. Section 6 makes some brief concluding remarks.

\section{A brief review of the economics of multi-sided platform markets}

There is an opportunity for a platform to increase social surplus when three necessary conditions are true: (1) there are distinct groups of customers; (2) a member of one group benefits from having his demand coordinated with one or more members of another group; and (3) an intermediary can facilitate that coordination more efficiently than bi-lateral relationships between the members of the group. ${ }^{1}$ As an empirical matter, indirect network effects generally accompany condition (2) and intimately shape the business strategies in these industries along side the multi-sidedness.

(1) There are two or more distinct groups of customers. These customers may be quite different from each other, such as the men and women for a dating platform or retailers and customers for a shopping mall. Alternatively, these customers may be different only for the purpose of the transaction at hand - eBay users are sometimes buyers, sometimes sellers; mobile phone users are sometimes callers, sometimes receivers.

(2) There are externalities associated with customers A and B becoming connected or coordinated in some fashion. A cardholder benefits when a merchant takes his card for payment; a merchant benefits when a cardholder has a form of payment he takes. The presence of indirect network effects seems to be an empirically important explanation for the emergence of a platform although not necessary as a matter of theory. Sellers of PEZ dispensers value exchanges that have more people who would like to buy PEZ dispensers. (See discussion of eBay below.)

(3) An intermediary can internalize the externalities created by one group for the other group. Obviously, if the members of group A and group B could enter into bilateral transactions

\footnotetext{
${ }^{1}$ See Rochet and Tirole (2002), Rochet and Tirole (2003), Rochet (2003), Armstrong (2002), and Parker and Van Alstyne (2002).
} 
they would be able to internalize the indirect externalities under the second condition (2). However, in practice information and transaction costs and free-riding problems make it difficult for members of distinct customer groups to internalize the externalities on their own. ${ }^{2}$ You can look for your new sweetheart by strolling around the Boston Public Garden; the Yahoo! Personals are less romantic but perhaps more efficient. The intermediary does not have to be a business in the usual sense. Cooperatives have emerged in payment cards (Visa International) and software (Linux). Governments sometimes act as the intermediary - currency is an example.

Several articles have examined the economics of price determination in multi-sided platform markets. A key finding is that optimal prices for the multiple customer groups must align - or balance - the demand among these groups - and indeed the emergence of a pricing structure as well as a pricing level is the defining characteristic of such industries (Rochet and Tirole, 2002). Optimal prices are not proportional to marginal costs as is the case with the familiar Lerner conditions $^{3}$ or its multi-product variants. ${ }^{4}$ Indeed, it is possible that the optimal price for one side will be less than the marginal cost for that side (Parker and Van Alstyne, 2002). (The assignment of costs to one side or another may not be well defined either. When it is necessary to get both sides together for a platform product to exist - that is for either customer to have anything to purchase - one may not be able to say that one side or another "caused" a cost.) Platform businesses may tend to skew prices towards one side or another depending upon the magnitude of the indirect network externalities resulting from that side. If side A generates a much greater degree of externalities for side B than side B does for side A, side A may tend to get a lower price (Parker and Van Alstyne, 2002). As in Ramsey-type models of multi-product pricing, in which firms are pricing in part to recover common costs of production, one side may end up contributing more to common costs than another side. However, the economic reasons for this are different in multi-sided than in single-sided markets. ${ }^{5}$ Note that the theoretical literature is based on quite rarefied assumptions and has thus far focused on static pricing issues.

The remainder of this article examines several multi-sided platform industries. It is helpful to divide multi-sided platforms into three categories: (1) market-makers; (2) audience-makers; and (3) demand coordinators. Table 1 provides further examples of multi-sided platform markets and businesses that participate in these markets. While by no means exhaustive, it illustrates the variety of multi-sided platform industries.

Market-makers enable members of distinct groups to transact with each other. Each member of a group values the service more highly if there are more members of the other group because that increases the likelihood of a match and reduces the time it takes to find an acceptable match. Examples include exchanges such as NASDAQ and eBay, shopping malls such as those that dot the New Jersey Turnpike, and dating services such as Yahoo! Personals. ${ }^{6}$

\footnotetext{
${ }^{2}$ In unpublished work Jean Tirole points out that a necessary condition for multi-sided platforms to arise is that the Coase Theorem does not apply.

${ }^{3}$ The Lerner condition was first stated in Lerner (1934).

${ }_{5}^{4}$ See generally Baumol, Panzar and Willig (1982).

${ }^{5}$ See generally Rochet and Tirole (2003), and Parker and Van Alstyne (2002).

${ }^{6}$ See NASDAQ (2003) "Market Characteristics" http://www.nasdaq.com/about/market characteristics.pdf, eBay Inc. (2003) "Company Overview," http://pages.ebay.com/community/aboutebay/overview/index.html, Pashigian and Gould (1998), and Yahoo! Inc. (2003) "Yahoo! Personals,” http://personals.yahoo.com/.
} 


\begin{tabular}{|c|c|c|c|c|c|c|}
\hline Industry & Two-Sided Platform & Category & Side One & Side Two & $\begin{array}{l}\text { Side that "Gets } \\
\text { Charged Least" }\end{array}$ & Sources of Revenue \\
\hline Real Estate & $\begin{array}{l}\text { Residential } \\
\text { Property Brokerage }\end{array}$ & $\begin{array}{l}\text { Market- } \\
\text { makers }\end{array}$ & Buyer & Seller & Side One & $\begin{array}{l}\text { Real estate brokers derive income principally } \\
\text { from sales commissions. }{ }^{\text {a }}\end{array}$ \\
\hline Real Estate & $\begin{array}{l}\text { Apartment } \\
\text { Brokerage }\end{array}$ & $\begin{array}{l}\text { Market- } \\
\text { makers }\end{array}$ & Renter & $\begin{array}{l}\text { Owner/ } \\
\text { Landlord }\end{array}$ & Typically Side One & $\begin{array}{l}\text { Apartment consultants and locater services } \\
\text { generally receive all of their revenue from the } \\
\text { apartment lessors once they have successfully } \\
\text { found tenants for the landlord. }\end{array}$ \\
\hline Media & $\begin{array}{l}\text { Newspapers and } \\
\text { Magazines }\end{array}$ & $\begin{array}{l}\text { Audience } \\
\text { makers }\end{array}$ & Reader & Advertiser & Side One & $\begin{array}{l}\text { Approximately } 80 \text { percent of newspaper revenue } \\
\text { comes from advertisers. }\end{array}$ \\
\hline Media & Network Television & $\begin{array}{l}\text { Audience } \\
\text { makers }\end{array}$ & Viewer & Advertiser & Side One & $\begin{array}{l}\text { For example, the FOX television network earns } \\
\text { its revenues primarily from advertisers. }{ }^{\text {d }}\end{array}$ \\
\hline Media & $\begin{array}{l}\text { Portals and Web } \\
\text { Pages }\end{array}$ & $\begin{array}{l}\text { Audience } \\
\text { makers }\end{array}$ & $\begin{array}{l}\text { Web } \\
\text { "Surfer" }\end{array}$ & Advertiser & Side One & $\begin{array}{l}\text { For example, Yahoo! earns } 75 \text { percent of its } \\
\text { revenues from advertising. }\end{array}$ \\
\hline Software & Operating System & $\begin{array}{l}\text { Demand } \\
\text { coordinators }\end{array}$ & $\begin{array}{l}\text { Applicatio } \\
\text { n User }\end{array}$ & $\begin{array}{l}\text { Application } \\
\text { Developer }\end{array}$ & Side Two & $\begin{array}{l}\text { For example, Microsoft earns at least } 67 \text { percent } \\
\text { of its revenues from licensing packaged } \\
\text { software to end-users. }{ }^{\text {. }}\end{array}$ \\
\hline Software & $\begin{array}{l}\text { Video Game } \\
\text { Console }\end{array}$ & $\begin{array}{l}\text { Demand } \\
\text { coordinators }\end{array}$ & $\begin{array}{l}\text { Game } \\
\text { Player }\end{array}$ & $\begin{array}{l}\text { Game } \\
\text { Developer }\end{array}$ & $\begin{array}{l}\text { Neither - Both sides } \\
\text { are significant } \\
\text { sources of platform } \\
\text { revenue }\end{array}$ & $\begin{array}{l}\text { Both game sales to end users and licensing to } \\
\text { third party developers are significant sources of } \\
\text { revenue for console manufacturers. Console } \\
\text { manufacturers have sold their video game } \\
\text { consoles near or below marginal cost (not taking } \\
\text { into account research and development). } \\
\text { Microsoft, for instance, is selling its Xbox for at } \\
\text { least } \$ 125 \text { below marginal cost. }\end{array}$ \\
\hline $\begin{array}{l}\text { Payment } \\
\text { Card System }\end{array}$ & Credit Card & $\begin{array}{l}\text { Demand } \\
\text { coordinators }\end{array}$ & Cardholder & Merchant & Side One & $\begin{array}{l}\text { For example, in } 2001, \text { American Express earned } \\
82 \text { percent of its revenues from merchants, } \\
\text { excluding finance charge revenue. }\end{array}$ \\
\hline
\end{tabular}

Table 1: Sources of revenue in selected two-sided platforms

Notes: "See Bureau of Labor Statistics, U.S. Department of Labor (2003) "Real Estate Brokers and Sales Agents," in Occupational Outlook Handbook, 2002-03 Edition, 362-364, http://www.bls.gov/oco/ocos120.htm. ' ${ }^{\mathrm{b}}$ See Ronan (1998). "See George and Waldfogel (2000). ${ }^{\mathrm{d}}$ See FOX (2000) "Annual Report". 'See Yahoo! Inc. (2001) "Annual Report." 'See IDC (1994) 1994 Worldwide Software Review and Forecast, Report \#9358, November, IDC (1995) 1995 Worldwide Software Review and Forecast, Report \# 10460, November, IDC (1996) 1996 Worldwide Software Review and Forecast, Report \#12408, November, IDC (1997) 1997 Worldwide Software Review and Forecast, Report \#14327, October, IDC (1999) 1999 Worldwide Software Review and Forecast, Report \#20161, October, IDC (2001) Worldwide Software

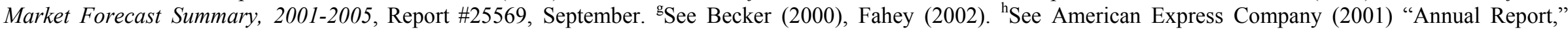
http://www.onlineproxy.com/amex/2002/ar/pdf/axp_ar_2001.pdf. 
Audience-makers match advertisers to audiences. Advertisers value the service more if there are more members of an audience who will react positively to their messages; audiences value the service more if there are more useful messages (Goettler, 1999). Advertising-supported media such as magazines, newspapers, free television, yellow pages, and many Internet portals are audience makers. ${ }^{7}$

Demand-coordinators make goods and services that generate indirect network effects across two or more groups. They are a residual category but economically the most interesting and the least studied. These platforms do not strictly sell "transactions" like a market maker or "messages" like an audience-maker. Software platforms such as Windows and the Palm OS, payment systems such as debit cards, and mobile telephones are examples (Rochet and Tirole, 2003). ${ }^{8}$

\section{Business models in multi-sided platform markets}

Several issues occur repeatedly in multi-sided platform markets: getting both sides on board; balancing interests; multihoming; scaling and liquidity.

\subsection{Getting both sides on board}

An important characteristic of two-sided markets is that the demand on each side tends to vanish if there is no demand on the other - regardless of what the price is. There are many references in the literature on the firms discussed earlier about solving the chicken-and-egg problem (Gawer and Cusumano, 2002). For example, there would be no demand by households for payment cards if they could not use them anywhere and no demand by retailers for payment cards if no one had them. Which comes first - the cardholder or the retailer (Evans and Schmalensee, 1999)? Men will not go to dating clubs that women do not attend because they cannot get a date. Merchants will not take a payment card if no customer carries it because no transaction will materialize. Computer users will not use an operating system that does not have applications they need to run. Sellers of corporate bonds will not use a trading mechanism that does not have any buyers. In all these cases, the businesses that participate in these industries have to figure out ways to get both sides on board. Investment and pricing strategies are keys to getting both sides on board.

One way to do this is to obtain a critical mass of users on one side of the market by giving them the service for free or even paying them to take it. Especially at the entry phase of firms in multi-sided markets, it is not surprising to see precisely this strategy. Diners Club gave its charge card away to cardholders at first - there was no annual fee and users got the benefit of the float. Netscape gave away its browser to most users to get a critical mass on the computer user side of the market; after Microsoft started giving away its browser to all users, Netscape followed suit

\footnotetext{
7 "In a fundamental sense, what advertisers demand, and what the various advertising media outlets supply, are units of audience for advertising messages. Thus advertiser demand for space in the print media and time in the broadcast media is a derived demand stemming from a demand for audience, and is a positive function of the size and quality of audience" (Ferguson, 1983).

${ }^{8}$ Mobile telephone services are not a one-sided market because most users both make and receive calls. A high termination charge raises the marginal cost of calls and lowers the marginal cost of call receptions. For a given call, end users are on a single side and their consumption behaviors depend on their own price (calling price for the caller and receiving price for the receiver). As a consequence, the choice of termination charge is not neutral. See Jeon, et al. (2001) for more detail.
} 
(Wong, 1998). Microsoft is reportedly subsidizing the sales of its Xbox hardware to consumers to get them on board (Becker, 2002). For monopoly and duopoly cases, if there is sufficient difference in the valuation of a transaction then the market with low valuation will be flooded in equilibrium and that type will pay zero price according to some recent theoretical work (Schiff, 2003).

Another way to solve the chicken-and-egg problem is to invest in one side of the market to lower the costs to consumers on that side of participating in the market. Microsoft provides a good example of this. As we saw earlier, it invests in applications writers by developing tools that help them write applications and providing other assistance that makes it easier for developers to write applications using Microsoft operating systems. To take another example, bond dealers take positions in their personal accounts for certain bonds they trade. They do this when the bond is thinly traded and the long time delays between buys and sells would hinder the market's pricing and/or liquidity. By investing in this manner, two-sided intermediaries are able to cultivate (or even initially supply) one side, or both sides, of their market in order to boost the overall success of the platform.

Providing low prices or transfers to one side of the market helps the platform solve the chicken-and-egg problem by encouraging the benefited group's participation - which in turn, due to network effects, encourages the non-benefited group's participation. Bernard Caillaud and Bruno Jullien (2001) refer to this strategy as "divide-and-conquer." Another effect of providing benefits to one side is that this assistance can discourage use of competing two-sided firms. For example, when Palm provides free tools and support to PDA applications software developers, it encourages those developers to write programs that work on the Palm OS platform, but it also induces those developers to spend less time writing programs for other operating systems (See discussion of Palm below.)

\subsection{Pricing strategies and balancing interests}

Firms in mature multi-sided markets - i.e. those that have already gone through the entry phase in which the focus is on solving the chicken-and-egg problem - still have to devise and maintain an optimal pricing structure. In most observed multi-sided markets, companies seem to settle on pricing structures that are heavily skewed towards one side of the market in the sense that the margin (price less marginal cost as a percent of price) is far less on one side than the other. Table 1 summarizes the pricing structure for some multi-sided markets. For example, in 2001, excluding finance charge revenue American Express earned 82 percent of its revenues from merchants. ${ }^{9}$ Microsoft earns the preponderance of its revenue from Windows from licensing Windows to computer manufacturers or end-users. ${ }^{10}$ Real estate brokers (for sales as opposed to

\footnotetext{
${ }^{9}$ If finance charge revenues are included, American Express earned 62 percent of its revenues from merchants in 2001 (American Express Company (2001) "Annual Report," http://www.onlineproxy.com/amex/2002/ar/pdf/axp_ar_2001.pdf.).

${ }^{10}$ From 1988 through 2000, Microsoft earned at least 67 percent of its revenues from licensing packaged software (such as Windows and Office) to end-users (either directly at retail or through manufacturer pre-installation on PCs). See IDC (1994) 1994 Worldwide Software Review and Forecast, Report \#9358, November, IDC (1995) 1995 Worldwide Software Review and Forecast, Report \# 10460, November, IDC (1996) 1996 Worldwide Software Review and Forecast, Report \#12408, November, IDC (1997) 1997 Worldwide Software Review and Forecast, Report \#14327, October, IDC (1999) 1999 Worldwide Software Review and Forecast, Report \#20161, October, IDC (2001) Worldwide Software Market Forecast Summary, 2001-2005, Report \#25569, September. Note that the 67 percent figure underestimates the amount of revenue Microsoft earns from end-users because the other third of revenue coming from "Applications Development and Deployment" includes some end-user revenues as well. For
} 
rent) usually earn most or all of their revenues from the sellers. Political tensions can also manifest themselves - looking out for their narrow interests, customers on each side of the market would like the other side to pay more. This is a familiar problem in the payment-card industry - in Europe a retailers association asked the European Commission to force the card associations to eliminate the interchange fee and this tension was behind the retailer litigation that was recently settled in the United States. ${ }^{11}$

Discerning the optimal pricing structure is one of the challenges of competing in a multisided market. Sometimes all the platforms converge on the same pricing strategy. Microsoft, Apple, IBM, Palm and other operating system companies could have charged higher fees to applications developers and lower fees to end-users. They all discovered that it made sense to charge developers relatively modest fees for developer kits and, especially in the case of Microsoft, to give a lot away for free. Nevertheless, Microsoft is known for putting far more effort into the developer side of the business than the other operating system companies (Gawer and Cusumano, 2002).

The debit card is an example in which different platforms made different pricing choices. In the late 1980s, the ATM networks had a base of cardholders who used their cards to withdraw cash or obtain other services at ATMs. They had no merchants that took these cards. To add debit services to existing ATM cards, the ATM networks charged a small interchange fee than the card associations charged (8 cents per transaction on a typical $\$ 30$ transaction compared) to encourage merchants to install PIN pads that could read the ATM cards that cardholders already had and accept the pins they used to access the ATM machines (Evans and Schmalensee, 1999). Many merchants invested in the PIN pads - the number of PIN pads increased from 53,000 in 1990 to about 3.6 million in 2001. ${ }^{12}$ The credit-card associations had a base of merchants who took their cards but it did not have cards that, like the ATM cards, accessed consumers' checking accounts. The credit-card systems imposed a much higher interchange fee than the ATM networks, about 37 cents versus 8 cents on a typical $\$ 30$ transaction. ${ }^{13}$ They did this to persuade banks to issue debit cards and cardholders to take these cards. ${ }^{14}$ The number of Visa debit cards in circulation increased from 7.6 million in 1990 to about 117 million in 2001. ${ }^{15}$

Two other factors influence the pricing structure. There may be certain customers on one side of the market - Rochet and Tirole refer to them as "marquee buyers" - that are extremely valuable to customers on the other side of the market. The existence of marquee buyers tends to reduce the price to all buyers and increases it to sellers. A similar phenomenon occurs when certain customers are extremely loyal to the two-sided firm - perhaps because of long-term contracts or sunk-cost investments. For example, American Express has been able to charge a relatively high merchant discount as compared to other card brands, especially for their corporate

example, database products used by business IT departments are included in the Applications Development category.

${ }^{11}$ See British Retail Consortium (2002) "Retail Disappointment as Visa Exempted from EU Competition Rules," Press Release, July 25, http://www.brc.org.uk/Archive.asp, Guerrera (2002), MacKintosh (2001), and Pacelle, Sapsford and Scannell (2003).

${ }^{12}$ See Evans and Schmalensee (1999) and The Nilson Report (2002) No. 759, March.

${ }^{13}$ The ATM systems typically charged a flat interchange fee per transaction, while the interchange fee set by Visa and MasterCard varied with the size of the transaction. The reported interchange fee comparison is from 1998, around the time of substantial growth in debit for the ATM and credit-card systems (Evans and Schmalensee, 1999).

${ }^{14}$ Visa attracted consumers through an effective advertising campaign and attracted issuers through heavy investment in a debit processing facility, among other strategies (Evans and Schmalensee, 1999).

${ }^{15}$ See The Nilson Report (2002) No. 760, March and The Nilson Report (1991) No. 500, May. 
card, because merchants viewed the American Express business clientele as extremely attractive. Corporate expense clients were "marquee" customers that allowed American Express to raise its prices to the other side of the market, merchants. In contrast, when the ATM systems entered into debit, they had "captive" cardholders - ATM cards could be used for debit transactions, so consumers did not need to be courted to accept the new payment form. Therefore, it has been the merchants - who must purchase and install expensive machinery in order to process online debit transactions - who have been courted, as we saw above.

\subsection{Types of platform market structures}

Several different multi-sided market organizations appear in practice. (1) Coincident platforms: several multi-sided platforms offer substitutable products or services on the same sides. That is the case in video games, operating systems, and payment cards. (2) Intersecting platforms: several $n$-sided platforms offer products or services that are substitutable on less than $n$ sides. Browsers were sides of operating system and internet portal businesses. ATM networks do not support credit cards or other cards that are not linked to the depository institution while credit card systems do not really offer ATM cards. (3) Monopoly platforms that have no competition on any side. Although this could exist in theory, of course, it is hard to identify any industry for which this has been true (yellow pages was an example for a time perhaps in some places).

Another aspect of platform competition concerns the extent to which users rely contemporaneously on more than one platform for a side. Users may be dedicated to one platform because it is not efficient or otherwise beneficial to use more than one network. For example, most users do not want to use more than one operating system on their personal digital assistant. Users may also find that it is beneficial and efficient to use several competing platforms - that situation has been called multihoming. Most merchants accept payment cards from several competing card systems.

Platform industries often have multihoming on at least one side. Table 2 presents a summary. Consider, for example, personal computers. One could consider the two sides as consisting of personal computer end-users and developers of applications. The end-users do not multihome. They almost always use a single operating system and by far the preponderance of them use a Microsoft operating system. ${ }^{16}$ The developers do multihome. According to Josh Lerner, in 2000, 68 percent of software firms developed software for Windows operating systems, 19 percent for Apple computers operating systems, 48 percent for Unix operating systems including Linux, and 36 percent and 34 percent for proprietary non-Unix operating systems that run on minicomputers and proprietary operating systems that run on mainframes respectively. ${ }^{17}$ In fact, in recent years the percentage of software firms developing for nonMicrosoft operating systems has increased. The fastest-growing category has been software firms developing for Unix operating systems including Linux. The percentage of developers in this category increased from 29 percent in 1998 to 48 percent in $2000 .^{18}$

Multihoming and intersecting platforms affect both the price level and the pricing structure. Theory and empirics are not far enough advanced to say much more.

\footnotetext{
${ }^{16}$ IDC (2001) Worldwide Software Market Forecast Summary, 2001-2005, Report \#25569, September.

17 The percentages total to 205, indicating substantial multihoming on the part of developers. See Lerner (2002) and Corporate Technology Directory (1990-2000).

${ }^{18}$ See Lerner (2002) and Corporate Technology Directory (1990-2000).
} 


\begin{tabular}{|c|c|c|c|c|}
\hline Two-Sided Platform & $\underline{\text { Side One }}$ & Presence of Multihoming for Side One & $\underline{\text { Side Two }}$ & Presence of Multihoming for Side Two \\
\hline $\begin{array}{l}\text { Residential Property } \\
\text { Brokerage }\end{array}$ & $\overline{\text { Buyer }}$ & $\begin{array}{l}\text { Uncommon: Multihoming may be unnecessary, since an MLS allows } \\
\text { buyers to see property listed by all member agencies. }{ }^{\text {a }}\end{array}$ & $\overline{\text { Seller }}$ & $\begin{array}{l}\text { Uncommon: Multihoming may be unnecessary, since an } \\
\text { MLS allows the listed property to be seen by all member } \\
\text { agencies' customers. }\end{array}$ \\
\hline Securities Brokerage & Buyer & 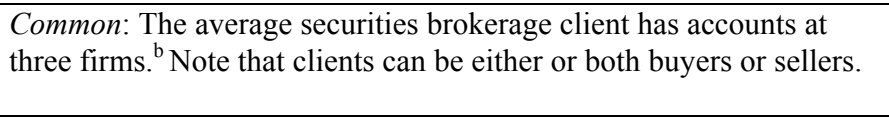 & Seller & $\begin{array}{l}\text { Common: The average securities brokerage client has } \\
\text { accounts at three firms. }{ }^{b} \text { As mentioned, clients can be either } \\
\text { or both buyers or sellers. }\end{array}$ \\
\hline Business-2-Business & Buyer & $\begin{array}{l}\text { Varies: For example, multihoming may be unnecessary for some } \\
\text { online B2B sites, since buyers can go directly to the B2B platform } \\
\text { instead of contacting multiple individual suppliers. }{ }^{{ }^{c}}\end{array}$ & Seller & $\begin{array}{l}\text { Varies: Multihoming may be unnecessary since the B2B } \\
\text { can inexpensively reach a large audience. }\end{array}$ \\
\hline Peer-2-Peer & Buyer & $\begin{array}{l}\text { Varies: Multihoming may be unnecessary for buyers using online } \\
\text { auction sites since eBay holds } 85 \% \text { of the market share (i.e. it seems } \\
\text { that most people purchase their online auction products at eBay). } \\
\text { Alternatively, multihoming may be more common for online dating } \\
\text { services where there are many sites and a large audience of online } \\
\text { singles (considered to be available singles, as opposed to buyers). }\end{array}$ & Seller & $\begin{array}{l}\text { Varies - Multihoming may be unnecessary for sellers using } \\
\text { online auction sites since eBay holds } 85 \% \text { of the market } \\
\text { share (i.e. it seems that most people auction their products } \\
\text { at eBay). Alternatively, multihoming may be more common } \\
\text { for online dating services where there are many sites and a } \\
\text { large audience of online singles (considered to be available } \\
\text { singles, as opposed to sellers). }{ }^{\text {e }}\end{array}$ \\
\hline $\begin{array}{l}\text { Newspapers and } \\
\text { Magazines }\end{array}$ & Reader & $\begin{array}{l}\text { Common: In 1996, the average number of magazines issues read per } \\
\text { person per month was } 12.3 .^{\mathrm{f}}\end{array}$ & Advertiser & $\begin{array}{l}\text { Common: For example, Sprint advertised in the New York } \\
\text { Times, Wall Street Journal, and Chicago Tribune, among } \\
\text { many other newspapers, on Aug. 20, 2002. }\end{array}$ \\
\hline Network Television & Viewer & $\begin{array}{l}\text { Common: For example, Boston, Chicago, Los Angeles, and Houston, } \\
\text { among other major metropolitan areas, have access to at least four } \\
\text { main network television channels: ABC, CBS, FOX, and NBC. }\end{array}$ & Advertiser & $\begin{array}{l}\text { Common: For example, Sprint places television } \\
\text { advertisements on ABC, CBS, FOX, and NBC. }\end{array}$ \\
\hline Operating System & $\begin{array}{l}\text { Application } \\
\text { User }\end{array}$ & Uncommon: Individuals typically use only one operating system. ${ }^{j}$ & $\begin{array}{l}\text { Application } \\
\text { Developer }\end{array}$ & $\begin{array}{l}\text { Common: As noted earlier, the number of developers that } \\
\text { develop for various operating systems indicates that } \\
\text { developers engage significant multihoming. }\end{array}$ \\
\hline Video Game Console & $\begin{array}{l}\text { Game } \\
\text { Player }\end{array}$ & $\begin{array}{l}\text { Varies: The average household (that owns at least one console) owns } \\
1.4 \text { consoles. }\end{array}$ & $\begin{array}{l}\text { Game } \\
\text { Developer }\end{array}$ & $\begin{array}{l}\text { Common: For example, Electronic Arts, a game developer, } \\
\text { develops for Nintendo's GameCube, Microsoft's Xbox, and } \\
\text { Sony's Playstation 2, among other consoles. }\end{array}$ \\
\hline Payment Card & Cardholder & $\begin{array}{l}\text { Common: Most American Express cardholders also carry at least one } \\
\text { Visa or MasterCard. }\end{array}$ & Merchant & $\begin{array}{l}\text { Common: American Express cardholders can use Visa and } \\
\text { MasterCard at almost all places that take American } \\
\text { Express. }\end{array}$ \\
\hline
\end{tabular}

Table 2: The presence of multihoming in selected two-sided platforms

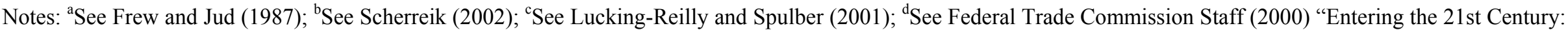
Competition Policy in the World of B2B Electronic Marketplaces: Efficiencies of B2B Electronic Marketplaces," October, http://www.ftc.gov/os/2000/10/index.htm\#26; ${ }^{\mathrm{e} S e e}$ Cisneros (2000) and Festa (1996); "See FCB (1998) "Magazines in the Information Age," Media Research Report, Spring, http://www.magazine.org/resources/research/fcb magazines infoage.html; ${ }^{g}$ See New York Times (2002), Wall Street Journal (2002), and Chicago Tribune (2002); "See ABC (2002) "Local Stations," http://abc.abcnews.go.com/site/localstations.html., CBS (2002) "CBS Info," http://www.cbs.com/info/hdtv/., FOX (2002) "Fox Affiliates,"

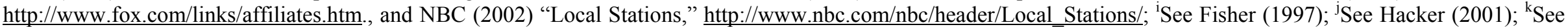
Lerner (2002) and Corporate Technology Directory (1990-2000); 'See Yankee Group (2001) "Video-Game Penetration Grows to 36 Million Households in 2001," Reuters News, November 19, http://about.reuters.com/newsreleases/art_19-11-2001_id785.asp; "'See "Game Makers Hedge Bets in Console Wars" (2001) USA Today, November 16, http://www.usatoday.com/life/cyber/tech/review/games/2001/11/19/game-makers.htm; ${ }^{\mathrm{n}}$ See Evans and Schmalensee (1999). 


\subsection{Scaling and liquidity}

Successful multi-sided firms such as Microsoft, eBay, Yahoo!, and Diners Club, have taken time to test and tweak their platforms to build liquidity before making major investments. These firms established presence in small markets first, and used trial and error to identify the correct technology and operations infrastructure in which to invest. Many successful multisided firms seem to adopt a fairly gradual entry strategy in which they scale up their platform over time. Though much of the network economics literature may suggest that the multisided firm should rely on the right initial investments to help build liquidity over time, it is often difficult to predict just what the right technology and operations infrastructure will be. Therefore, successful multi-sided firm seem to found it advantageous to establish efficient buy-seller transactions first, and make large investments only after the platform has been tested. For instance, eBay expanded outside the collectibles market only when users started listing such items up for sale. Figure 1 below outlines the growth of eBay's sales categories. It shows the gross merchandise sales per category in the third quarter of 2002 broken down by category. The three categories - collectibles, early practicals, and practicals - are grouped by the year they debuted.

\begin{tabular}{|c|c|c|c|}
\hline Category & Q3-02 (millions) & $\underline{Y r / Y r}$ & \\
\hline Collectibles: & & & \multirow{3}{*}{ Debuted First $\sim 1995$} \\
\hline Collectibles & $\$ 920$ & $11 \%$ & \\
\hline Coins \& Stamps & $\$ 400$ & $51 \% \sqrt{\downarrow}$ & \\
\hline Early Practicals: & & & \multirow{5}{*}{ Debuted Second $\sim 1997$} \\
\hline Computers & $\$ 1,600$ & $44 \%$ & \\
\hline Consumer Electronics & $\$ 1,400$ & $78 \%$ & \\
\hline Books, Movies, Music & $\$ 1,200$ & $44 \%$ & \\
\hline Sports & $\$ 1,000$ & $35 \%$ & \\
\hline Practicals: & & & \multirow{4}{*}{ Debuted Third $\sim 1999$} \\
\hline Motors & $\$ 3,800$ & $116 \%$ & \\
\hline Clothing & $\$ 700$ & $98 \%$ & \\
\hline Home \& Garden & $\$ 470$ & $90 \%$ & \\
\hline
\end{tabular}

Figure 1: eBay's category growth ${ }^{19}$

Palm also did not invest large amounts into developer support until it achieved sufficient liquidity on the user side of the market. While small investments were made in releasing a software development kit (SDK) with the Palm Pilot and making the Palm OS and architecture accessible to outside developers, Palm made few efforts to sign up key development partners or to support the Palm development community through classes, conferences, and other community support activities until a critical mass of users was assembled in 1998. (See discussion of Palm below.)

Many successful multi-sided firms have tested and modified their platforms with minimal investment and then scaled up according to what works best. An example comes from Yahoo!, a firm that has, over time, experimented with providing pages geared to different audiences such as Yahoo!Personals, Yahoo!Finance, and Yahoo!Travel. In 1996, Yahoo! developed Yahooligans!, a directory site that linked to content that appealed to children. ${ }^{20}$ Yahoo! invested only one programmer and one business developer in their early efforts on

${ }^{19}$ See eBay Inc. (2001) "Annual Report."

${ }^{20}$ See http://www.yahooligans.com. 
Yahooligans!, both working half time for three months before the launch. As it turned out, the bandwidth available to most children at the time - $28 \mathrm{kbps}$ - was too slow to allow for content that kept kids' attention. Yahooligans! was a relative failure among Yahoo! pages at the time, but that failure came at a minimal loss to Yahoo! (Bergin, 1998).

A final observation on business models. Contrary to the traditional economic theory of network effects (Arthur, 1989) and the business advice based on that theory (Shapiro and Varian, 1999), there is no evidence that building up market share quickly is a recipe for market domination in platform industries most, if not all of which, are precisely those industries that economists have cited as having strong network effects. Many of the early entrants in these industries ultimately did not retain the leadership position: Diners Club in cards, Apple in personal computer, Apple in hand-held devices, and OnSale in on-line exchanges. Also, as noted above, despite network effects many platform industries have several overlapping competing platforms and most have multi-homing on at least one side.

\section{$4 \quad$ Diners Club and pricing in the payment card industry}

Frank McNamara, the president of a New York credit company, was having lunch in Manhattan in 1949. A year later he had a thriving business based on this experience. According to Newsweek: $:^{21}$

"Halfway through his coffee, McNamara made a familiar, embarrassing discovery; he had left his wallet at home. By the time his wife arrived and the tab had been settled, McNamara was deep in thought." Result: the "Diners Club," one of the fastest-growing service organizations.

McNamara and an associate, Ralph Schneider, started small. Beginning with less than \$1.6 million (in 2002 dollars) ${ }^{22}$ of start-up capital they signed up 14 New York restaurants, charging them 7 percent of the tab, and initially gave cards away to people. ${ }^{23}$ (The observant reader will note that for must of us owning a credit card would not help our predicament when we leave our wallets at home. The proverbial apple falling on the head is a mysterious force.)

By its first anniversary there were 42,000 cardholders who were each paying $\$ 18$ year for membership in the "club." There were 330 U.S. restaurants, hotels and nightclubs that accepted these cards; they paid an average of 7 percent of the cardholder's bill to Diners Club. In March 1951, Diners Club handled about \$3 million of exchanges between cardholders and merchants (it reportedly made almost $\$ 60,000$ in profit before taxes). ${ }^{24}$ In 1951 Frank McNamara, founder of Diners Club, predicted that monthly transaction volume would increase to about $\$ 7$ million by the end of the year. ${ }^{25}$ Diners Club was therefore getting more than three quarters of its revenues from merchants. ${ }^{26}$ Moreover, the margin on cardholders was low since they were getting free float for an average of two weeks.

By 1958, it had raised the cardholder fee to about $\$ 26$ but left the merchant fee at 7 percent. Nevertheless, it continued to earn most of its revenues, about 70 percent, from merchants. ${ }^{27}$ The same year saw the birth of two of the major competitors to Diners Club. American Express, which had long been in the travel and entertainment business with its travelers checks and travel offices, decided to enter the industry. It recognized need to get

\footnotetext{
21 "Dining on the Cuff" (1951) Newsweek, January 29.

${ }^{22}$ Except where noted, all dollar figures in this paper have been adjusted to constant 2002 dollars.

${ }^{23}$ See Mandell (1990) and Grossman (1987).

24 "Charge It, Please" (1951) Time, April 9.

25 "Dining on the Cuff" (1951) Newsweek, January 29.

${ }^{26}$ Cardholder fees totaled about $\$ 745,000$ while merchant fees totaled about $\$ 2.5$ million.

27 “On-the-Cuff Travel Speeds Up” (1958) Business Week, August 16.
} 
both sides on board. Even before the first transaction, it had already acquired a cardholder base of 150,000 from the American Hotel Association's card program, as well as the program's 4,500 hotels for its merchant base. It bought another 40,000 cardholders from Gourmet magazine's dining card program (Grossman, 1987). It soon had a cardholder base to sell to T\&E merchants, and sent out representative to sign them up. It also advertised in newspapers for additional cardholders (Grossman, 1987). American Express's positive reputation in the T\&E industry was also a benefit in attracting both sides of the business (Grossman, 1987). By the time of its entry on October 1958, it already had 17,500 merchant locations and 250,000 cardholders (Grossman, 1987).

American Express adopted a slightly different pricing policy than Diners Club. It initially set its annual fee at $\$ 31, \$ 5$ higher than Diners Club, thereby suggesting that it was the more "exclusive" card (Friedman and Meehan, 1992). But it set the initial merchant discount slightly lower: 5 to 7 percent for restaurants; and 3 to 5 percent for the recalcitrant hotel industry. ${ }^{28}$ Within a year, its cardholder base had grown to 700,000 and its merchant base to $37,000 .^{29}$ With its slightly higher cardholder fee and slightly lower merchant fee, American Express received just under 55 percent of its revenue from merchants, compared to over 65 percent for Diners Club in 1959.30 This would grow over time, however, as spending per card increased faster than annual fees.

American Express had been successful getting both sides on board but initially struggled to make a profit. It responded by putting more pressure on cardholders to pay promptly. It also managed to raise cardholder fees without suffering significant attrition. There were 900,000 cardholders that could use their cards at 82,000 merchant locations by the end of 1962, the first year that the card operation posted a small profit (Hammer, 1962).

The other significant entrant in 1958 was Bank of America (this card evolved into Visa). Unlike many other banks, it had always focused on lending money to the middle class. By 1958, Bank of America had extensive experience in making small loans on consumer durables such as refrigerators and automobiles. It had also become the largest bank in the country (Mandell, 1990).

One of its small competitors, the First National Bank of San Jose, started a charge card in 1953. At the time, Bank of America considered introducing its own card but decided that there was not a good enough business case. After studying the emerging industry over the next few years they decided to introduce a credit card. Credit-worthy customers would receive cards with limits of either $\$ 1,600$ or $\$ 2,600$; prior authorization would be required for purchases over $\$ 130$; and a revolving credit option was available for some cardholders (Wolters, 2000). Revolving credit was the feature that distinguished this card from existing charge cards. The merchant fee was initially set at 5 percent and lowered soon thereafter (Wolters, 2000). Cardholders did not pay an annual fee but paid finance charges on any revolved balances at an annual interest rate of 18 percent (Wolters, 2000). This was a more merchant-friendly balance than that set by Diners Club or American Express, especially considering that Bank of America's card was also extending credit on a revolving basis.

Bank of America did a market test in Fresno in the fall of 1958. Three hundred retailers signed up initially, and every Bank of America customer in the Fresno area received a card. According to one study, "This mass mailing of 60,000 cards had been William's (the Bank of America leader of the effort) solution to the problem of how to convince retailers that enough individuals would possess a card to make their participation in the program worthwhile. His

\footnotetext{
28 "On-the-Cuff Travel Speeds Up" (1958) Business Week, August 16.

29 "Towards an Ever-Fuller Life on Credit Cards" (1959) Newsweek, September 28.

${ }^{30}$ Figures taken from Newsweek 1959 article, and assuming average of 5 percent for Amex per Newsweek 1958 article.
} 
solution worked, for during the next five months another eight hundred Fresno-area retailers joined the newly named 'BankAmericard' program" (Wolters, 2000). They expanded throughout the state during the following year. By the end of 1959, 25,000 merchants accepted the card and almost two million California households had one.

Things did not go well. Fraud was rampant. The number of delinquent accounts was five times higher than expected. Large retailers resisted joining. The program lost $\$ 45$ million in 1960. The bank worked on collection problems and lowered the merchant fee to as low as three percent to entice retailers. Delinquencies declined and the merchant base increased to 35,000 in 1962 . It was profitable by the early to mid 1960s.

One notable common theme across the experiences of the three startups is the importance of getting both sides on board. Diners Club, starting from scratch and trying to sell a new product, had to build slowly. It set a relatively cardholder-friendly balance, collecting most of its revenues from merchants. This made it possible to sign up cardholders even before a significant merchant base had been signed. The cardholder base could then be used, of course, to sign up merchants. By the time of American Express's entry, the idea of a charge card had already been established by Diners Club and others. American Express was able to capitalize on that by entering at a larger scale. Indeed, it probably did not have the option of entering as gradually as Diners Club did, since what cardholders or merchants would sign up with a fledgling American Express card given the option of an established alternative. American Express therefore bought up customer bases on both sides before it entered. It was also able to use its established position in the T\&E business to set a slightly higher cardholder fee, to cultivate the upscale image that served it well for a long time.

Bank of America also developed a large cardholder base in entering the business. It used its base of depository customers, the largest in California, to develop an instant cardholder base, which it then used to sign up merchants. Even with its prominent position among consumers in California, however, Bank of America had to strike a more merchant-friendly balance, lowering its merchant fees until it could get enough merchants on board.

Perhaps as a consequence of entering at a larger scale, both American Express and Bank of America, unlike Diners Club, had a hard time making a profit early on. Diners Club made a profit in its first year, while the other two firms did not see a profit until their fourth or fifth years. It took time to weed out delinquent cardholders. Having to make an upfront investment in building a profitable cardholder base is a lesson that holds even for new card issuers today (although they can join Visa or MasterCard and do not have to build an entire system). There were also the operational problems that would be expected in starting up any new business. Bank of America had such (misplaced) confidence its customers would pay their bills that it did not even set up a collections department (Nocera, 1994).

\section{$5 \quad$ The Palm OS and community-building in software platforms}

Palm was founded in 1992 as an effort to develop software applications for personal digital assistants (PDAs). In 1993, Palm released the Zoomer in collaboration with five other companies - Casio, GeoWorks, Tandy, Intuit, and America Online. Palm was responsible for the application development while the other five companies handled the hardware, the operating system, and distribution. The Zoomer, with its high price (\$820) and poor handwriting recognition, ultimately failed with only 15,000 units sold (Gawer and Cusumano, 2002). Zoomer was not the first failure. Apple had made the first attempt with its Apple Newton in 1993. Other entrants into the PDA market from 1993 to 1996 were the Psion Series 3, Hewlett-Packard LX, Hewlett-Packard OmniGo, Sharp Zaurus, Sharp Wizard, 
and Microsoft's Windows CE ${ }^{31}$ PDAs. With the exception of the Windows CE PDA, all followed an integrated strategy where the PDA manufacturer produced the hardware, operating system, and applications. Windows CE PDAs had a non-integrated strategy, where the hardware, operating system, applications were all developed by different firms (although Microsoft did end up writing the operating system as well as many applications for Windows $\mathrm{CE}$ ). The integration of application and operating system development within one firm was common in the software industry, for example Microsoft produced some of the most popular applications for the Windows OS (Evans, 2003).

Palm re-entered the handheld market in 1996 with the Palm Pilot. This integrated hardware, an operating system, and some applications. Palm overcame the handwriting recognition hurdle with the invention the Graffiti text entry method, providing users a simple method to enter text. Industry experts described Graffiti as the "killer app" for the Palm Pilot (Feldstein and Flanagan, 2001). The pricing of the Palm Pilot also reflected Palm's desire to have deep market penetration. While 3Com, Palm's parent company from June 1997 to March 2000, wanted Palm to price the Palm Pilot high to extract profits, Palm insisted that prices be kept low to expand the user base (Gawer and Cusumano, 2002). The Palm Pilot's combination of low price and robust features were a hit with consumers and provided the "most bang for the buck" (Atluru and Wasserstein, 1998). The Palm Pilot met immediate success with over 360,000 units sold in 1996, representing 51 percent share of the market (Atluru and Wasserstein, 1998). ${ }^{32}$

Palm has gone through three stages in developing what is now a three-sided platform business. In the first phase from about 1996 to 1998, it entered as an integrated platform. It made the hardware, operating system, and applications for the Palm Pilot and integrated them together. It planned to court developers, however, only after it had a significant user base. According to Donna Dubinsky, CEO and one of its founders, "We are a highly integrated product that delivers end user results. We are not having a developer conference until we sell a million units" (Atluru and Wasserstein, 1998). A developer conference is one of the major methods used by software platforms to stimulate the writing of applications. Nevertheless, even during this initial phase Palm laid the groundwork for getting a developer community on board. ${ }^{33}$ In early 1996, Palm released its first software development kit (SDK), which included the source code for the Palm Pilot's bundled applications. This source code served as a model that outside developers could reference to build other applications (Gawer and Cusumano, 2002).

In 1998, Palm sold over 2 million PDAs and launched the second phase of market development. Palm invested resources in persuading developers to write applications for the Palm OS. It offered business development resources to developers, including joint development, marketing, and bundling. Palm's most important business development resource was its software development forums (SDF), which helped external developers start and grow their own businesses. The SDF offered advisory meetings, business seminars, workshops, and networking events. It also started a \$54 million venture capital unit called Palm Ventures to support businesses focusing on Palm OS applications. The company also offered Palm OS development classes regularly, and encouraged other activities among its community of users through developer portals (Gawer and Cusumano, 2002). The strategy to actively get developers on board was successful. The number of registered developers grew

\footnotetext{
${ }^{31}$ Windows CE was renamed Pocket PC at version 6.0.

32 This represents market share of Palm hardware PDA and does not include licensed Palm OS devices.

${ }^{33}$ In fact, in the first year of release, the Palm attracted over 2,000 third-party developers to its platform without any developer support efforts (Atluru and Wasserstein, 1998).
} 
from 7,500 in 1998 to 220,000 in $2002 .{ }^{34}$ Palm continued to secure its market leadership, with over 7 million units shipped by 2000 .

The third phase, from about 2001 to the present, has moved Palm closer to being a pure operating system company. Palm has created alliances with Sony, Nokia, Handspring, IBM, Qualcomm, Supra, Symbol Technologies, Fossil ${ }^{35}$, and TRG Products to create PDAs and other computer appliances based on the Palm OS (Gawer and Cusumano, 2002). Palm has reported that this greatly increases the market share of Palm OS based PDAs over their potential market share with an integrated strategy. ${ }^{36}$ In addition, Palm OS licensing has expanded the scope of the Palm OS beyond traditional PDAs to such devices as wrist watches (Fossil Wrist PDA), cellular phones (Handspring Treo), and multimedia players (Sony Cliè). While Palm manufactured PDAs claimed 50 percent of the market in 2000, devices powered by the Palm OS operating system had over 75 percent share of the worldwide personal companion device market according to a report by International Data Corporation. ${ }^{37}$ This market share increased to over 82 percent by the second half of $2002 .{ }^{38}$ In January 2002 as Palm powered devices hit 20 million sold, Palm formed a Palm OS platform subsidiary, PalmSource, further separating the Palm OS from Palm's hardware solutions. ${ }^{39}$

Palm claims that its operating system was designed from the start to provide a platform for these three sides. According to Palm's web site,

"From the start, the flexible, extensible Palm OS has been designed to grow and evolve in response to user needs. The open, modular architecture allows our more than 50,000 developers, licensees, alliance, and OEM partners to develop innovative new products and applications for a rapidly expanding global market" (Gawer and Cusumano, 2002).

Palm has subsidized both the application developer side of the market and the user side of the market by licensing their operating system at a loss and giving their development tools away for free. It is able to do this because of its profits in hardware sales. Palm provides an SDK, Palm OS Emulator, Palm OS Simulator, and sample source code free for download on its web site. Palm also provides links to third-party integrated development environments, both free and not, for download on their web site. ${ }^{40}$ Palm also offers an online developer support program to offer a full range of development services. The Basic Level Membership is offered at no cost. The Advanced Level Membership is available for just $\$ 500$ per year and includes direct technical, marketing and training support. ${ }^{41}$ Only a small percentage of Palm's revenues were from licensing of the Palm OS. PalmSource revenues totaled $\$ 67, \$ 88$, and $\$ 50$ million, while operating loss totaled $\$ 17, \$ 8$, and $\$ 8$ million in fiscal years 2002, 2001 and 2000, respectively. ${ }^{42}$ This continued loss of PalmSource represents Palm's continued efforts in trying to expand the user base of the Palm platform.

\footnotetext{
${ }^{34}$ Palm, Inc. (1998) "Key Strategic Relationships And Growth To 7,500 Developers Propel 3Com Palm Computing ${ }^{\circledR}$ Platform Into Corporate America,” June 15, http://www.palm.com/pr/enterprise.html; Palm, Inc. (2002) "Annual Report."

${ }^{35}$ Palm, Inc. (2002) "Fossil Signs License Agreement with PalmSource For First Ever Palm Powered Wrist Devices,” November 18, http://www.palmsource.com/press/2002/111802.html.

${ }^{36}$ Palm, Inc. (2001) "Annual Report."

${ }^{38}$ Palm, Inc. (2003) "Palm Powered Share Increases in Second Half of 2002,” January 27, http://www.palmsource.com/press/2003/012703.html.

${ }^{39}$ Palm, Inc. (2002) "Palm Completes Formation of Palm OS Subsidiary as Palm Powered Devices Hit 20 Million Sold,” January 21, http://www.palmsource.com/press/2002/012102.html.

${ }^{40}$ Palm, Inc. (2003) "PalmOS: Desktop Development," http://www.palmos.com/dev/tools.

${ }^{41}$ Palm, Inc. (2003) "PalmOS.com: Palm OS Developer Program,” http://www.palmos.com/dev/programs/pdp.

42 Palm, Inc. (2002) “Annual Report.”
} 


\section{Summary}

Multi-sided platform markets are becoming an increasingly important part of the economy. They range from relatively small emerging companies like eBay, Yahoo!, and Palm, to relatively large and mature companies like American Express. These markets also have had a large impact on the recent information technology boom, and undoubtedly, they will continue to be important, as internet based commerce expands its scope to include both new and old economy firms. In addition to internet commerce, other increasingly important industries, such as credit cards, operating systems, shopping centers, and mass media, are all governed by the economics of multi-sided platforms.

While it is not my intention to generalize from a small sample, and many issues need to be investigated in more depth, a number of business models appear common across both the cases studied here. First, differential pricing is used to get both sides on board. Second, once both sides are on board, pricing continues to play a key role in maintaining both sides of the platform. Third, multihoming often occurs in multi-sided platforms. And, fourth, one solution to the pricing complexity that has been used successfully is to start with a small but scalable platform.

\section{$7 \quad$ References}

Armstrong, Mark (2002) "Competition in Two-Sided Markets," Nuffield College, Oxford, Working Paper.

Arthur, W. Brian (1989) "Competing Technologies, Increasing Returns, and Lock-In By Historical Events,” The Economic Journal, 99: 116-131.

Atluru, Rajesh and Kevin Wasserstein (1998) "Palm Computing: The Pilot Organizer," Harvard Business School.

Baumol, William, John C. Panzar and Robert D. Willig (1982) Contestable Markets and The Theory of Industry Structure, Harcourt Brace Jovanovich, New York.

Becker, David (2000) "Revenue from Game Consoles will Plunge, Report Predicts," CNET News.com, July 31, http://techrepublic-cnet.com.com/2100-1040-43841.html?legacy=cnet.

Becker, David (2002) "Xbox Drags on Microsoft Profit," CNET News.com, Jan. 18, http://news.com.com/2100-1040-818798.html.

Bergin, Richard (1998) "Interview with Yahoo! Senior Vice President Tim Brady," Harvard Business School, doctoral research.

Caillaud, Bernard and Bruno Jullien (2001) "Chicken \& Egg: Competing Matchmakers," Center For Economic Policy Research, Working Paper No. 2885.

Cisneros, Oscar S (2000) "Ebay Accused of Monopolization," Wired News, July 31, http://www.wired.com/news/print/0,1294,37871,00.html.

Evans, David S. (2003) “The Antitrust Economics of Multi-Sided Platform Markets," Yale Journal on Regulation (forthcoming). 
Evans, David S. and Richard Schmalensee (1999) Paying with Plastic: The Digital Revolution in Buying and Borrowing, The MIT Press, Cambridge, MA.

Fahey, Rob (2002) "MS to Lose J525M on Xbox This Year," GameIndustry.biz, June 26, http://www.gamesindustry.biz/content page.php?section name=pub\&aid=210.

Feldstein, Janet and Christopher Flanagan (2001) "Handspring - Partnerships," Harvard Business School.

Ferguson, James M. (1983) "Daily Newspaper Advertising Rates, Local Media CrossOwnership, Newspaper Chains, and Media Competition," Journal of Law and Economics, 26: 635-654.

Festa, Paul (1996) "Looking for Love Online," CNET News.com, December 17, 1996 http://news.com.com/2100-1023-255523.html?tag=rn.

Fisher, James (1997) “An Ad Blitz for the $21^{\text {st }}$ Century,” Sprint Press Release, September 24, http://www3.sprint.com/PR/CDA/PR_CDA_Press_Releases_Detail/0,3245,00.html?ID=129 $\underline{4}$.

Frew, J. and G. Jud (1987) "Who Pays the Real Estate Broker's Commission?" Research in Law and Economics: The Economics of Urban Property Rights, 10: 177-188.

Friedman, Jon and John Meehan (1992) House of Cards: Inside the Troubled Empire of American Express, Putnam, New York.

Gawer, Annabelle and Michael A. Cusumano (2002) Platform Leadership, Harvard Business School Press, Boston, MA.

George, Lisa and Joel Waldfogel (2000) "Who Benefits Whom in Daily Newspaper Markets?” NBER Working Paper \#7944.

Goettler, Ronald. (1999) "Advertising Rates, Audience Composition, and Competition in the Network Television Industry,” Carnegie Mellon University GSIA Working Paper \#1999-E28.

Grossman, Peter (1987) American Express: The Unofficial History of the People Who Built the Great Empire, Crown Publishers, New York.

Guerrera, Francesco (2002) "Brussels Set to Let Visa off the Hook," Financial Times, May 13.

Hacker, Scot (2001) "He Who Controls the Bootloader," Byte, August, http://www.byte.com/documents/s=1115/byt20010824s0001/0827 hacker.html.

Hammer, Alexander R. (1962) "American Express Raises Profit: Credit Card Unit in the Black," The New York Times, April 25.

Jeon, Doh-Shin, Jean-Jacques Laffont, and Jean Tirole (2001) "On the Receiver Pays Principle," mimeo.

Jullien, Bruno (2001) "Competing in Network Industries: Divide and Conquer," Institut D’Economie Industrielle, Working Paper No. 9. 
Lerner, Abba (1934) "The Concept of Monopoly and the Measurement of Monopoly Power," Review of Economic Studies, 1: 157-175.

Lerner, Josh (2002) "Did Microsoft Deter Software Innovation?" Working Paper, http://papers.ssrn.com/sol3/delivery.cfm/SSRN ID269498 code010528670.pdf?abstractid=2 $\underline{69498 .}$

Lucking-Reilly, David. and Daniel F. Spulber (2001) "Business-to-Business Electronic Commerce," Journal of Economic Perspectives, 15: 55-68.

MacKintosh, James (2001) "Watchdog Rules Credit Card Fees to Retailers Excessive," Financial Times, September 26.

Mandell, Lewis (1990) The Credit Card Industry: A History, Twayne Publishers, Boston, MA.

Nocera, Joseph. (1994) A Piece of the Action: How the Middle Class Joined the Money Class, Simon \& Schuster, New York.

Pacelle, Mitchell, Jathon Sapsford and Kara Scannell (2003) "Visa to Settle With Retailers for \$2 Billion," The Wall Street Journal, May 1.

Parker, Geoffrey and Marshall W. Van Alstyne (2002) "Unbundling the Presence of Network Externalities," Working Paper, http://www.idei.asso.fr/Commun/Conferences/Internet/Janvier2003/Papiers/VanAl.pdf.

Pashigian, B. Peter and Eric D. Gould (1998) "Internalizing Externalities: The Pricing of Space in Shopping Malls," Journal of Law and Economics, 41: 115-142.

Rochet, Jean-Charles (2003) "The Theory of Interchange Fees: A Synthesis of Recent Contributions," Working Paper.

Rochet, Jean-Charles and Jean Tirole (2002) "Cooperation Among Competitors: Some Economics of Payment Card Associations," Rand Journal of Economics, 33: 549-570.

Rochet, Jean-Charles and Jean Tirole (2003) "Platform Competition in Two-Sided Markets," Journal of the European Economics Association (forthcoming).

Ronan, Courtney (1998) “Apartment Locaters: How Do They Make Their Money?” Realty Times, June 30, http://realtytimes.com/rtnews/rtcpages/19980630_aptlocator.htm.

Rysman, Marc (2002) "Competition Between Networks: A Study of the Market for Yellow Pages 1-2,” Boston University Industrial Studies Project, Working Paper No. 104.

Scherreik, Susan (2002) "Is Your Broker Leaving You Out in the Cold?" Business Week, http://www.businessweek.com/magazine/content/02_07/b3770110.htm.

Schiff, Aaron (2003) "Open and Closed Systems of Two-Sided Networks," Information Economics and Policy, forthcoming.

Shapiro, Carl and Hal R. Varian (1999) Information Rules, Harvard Business School Press, Boston, MA. 
Wolters, Timothy (2000) "Carry Your Credit Card in Your Pocket: The Early History of the Credit Card at Bank of America and Chase Manhattan," Enterprise and Society, 1: 315-354.

Wong, Wylie (1998) "Netscape Applauds Microsoft Suit," TechWeb, May 20, http://www.techweb.com/wire/story/msftdoj/TWB19980519S0007. 